\title{
THE PART OF NÉBIH HAS IN GIVING INFORMATION AND EXAMINATION OF CONSUMER BEHAVIOUR ACCORDING TO THE RELATING POINTS
}

\author{
${ }^{1}$ Brigitta Zsótér, ${ }^{2}$ Cintia Borbíró \\ ${ }^{1}$ Szegedi Tudományegyetem Mérnöki Kar, Mars tér 7., 6724, Szeged, Hungary, \\ e-mail: zsoterb@mk.u-szeged.hu \\ ${ }^{2}$ Szegedi Tudományegyetem Mérnöki Kar, Mars tér 7., 6724, Szeged, Hungary, \\ e-mail: borbiro.cintia@gmail.com
}

\begin{abstract}
The subjects of the research are the part of the NÉBIH has in giving information and the examination of consumer behaviour according to the relating points. The place of the research was Földeák. This is a typical settlement in county Csongrad. A questionnaire survey was completed by 152 people. Most of the answerers said that although the NÉBIH helps them orientate within news on food, it is still the family and the traditions are the factors which influence decision making even today. Regarding commercials, brief ones which are rich in information are the most popular with the answerers. More and more people check the packing of the product before buying it, and they consider the information placed on it useful. They might as well change their purchase intent because of it, though the results show that it is still people with higher education that can understand the nutrition information. Only customers with higher income can place safety and quality before price, and consumption of healthy food is pushed into the background even in case of average or under average state of health. Purchase of Hungarian products or products processed in Hungary is especially important for the age group 18-34.
\end{abstract}

\section{INTRODUCTION}

The choice of the subject was supported by a chapter of a book entitled „Nutrition marketing" („Táplálkozásmarketing” in Hungarian) written by Zoltán Szakály, published in 2011 [1] which lists the factors typical to the conscious costumer. The customer behaviour is connected to the work of the National Food Chain Safety Agency (NÉBIH) in several points. They intend to inform customers, to give them trustworthy pieces of information, by so doing to invite them to see value in food safety and quality, in the known origin, so in the Hungarian product, in the domestic product and in the home-processed product, which they have to pay attention to. To achieve these goals, they have to influence the customer behaviour [2] and habits [3] [4] in a way for which we can find examples in our everyday routine, like bills, advertisements, the official website of NÉBIH. It is worth having a closer look at what customers think of these things. Does the information reach them, and if so, do they use it, or do they understand it, at all?

\section{A BRIEF SUMMARY OF THE RELATING LITERATURE}

Concepts and research results in connection with the given subject have been summarised by a secondary research. The most important one seems to be the concept of food safety which means, according to Laczay [5], that it is ensured during the whole process of food production, storage and distribution that the food will not endanger the consumer's health if it is processed and consumed according to its purpose. The importance of the National Food Chain Safety Agency is strongly connected to this definition, how they can have part in communication with consumers. The role of information is vital since without the necessary information [6], the food purchaser and consumer makes decision without the appropriate information the basic cases of which are the following:

1. The whole information on the products is not available

2. The costumer cannot integrate the available information into his/her decisions

3. The information supply of the seller and the costumer is symmetric but that of the costumer is generally less

4. The consumer decisions are generally built on assumptions [7].

Research results, which were made in May 2009 by questioning 630 people, published by Dörnyei [8] have been summarised in charts and have been used to compile our questionnaire and to make comparisons. In 


\section{ISSN 2064-7964}

his research he examined the attitude of the Hungarian population to the label use. Also, he analysed how consumers get information on the food in the framework of a non-representative survey made with voluntary, anonymous polling. We also used a part of the research completed by Zoltán Szakály and his colleagues [9] [10] further results of research by Berke and Varga [11] in which they showed what the attitude of the Hungarian consumers to advertising tools and commercials have. They completed more research using questionnaire surveys in which they focused mostly on dairy products. We are intending to show some of their results which have relevant information for our research, too. In some of their questions they asked customers what makes a good commercial. They asked open-ended questions in their questionnaire which showed that consumers - mostly women in the age-group 19-29 - prefer funny, light advertisements. However, it often distracts the attention from the real message or content.

\section{MATERIAL AND METHOD}

We carried out a quantitative questionnaire survey within the primary research. The questionnaire is the structured method of data collection which makes giving information both in written and oral forms possible [12]. The compiled questionnaire included open-ended and interval scale questions, also it contained ordinal scale ones, as well. Using more types of questions proved to be useful in order to get a sharper result. During the primary research 152 questionnaires were completed in Földeák, between 17 and 23 August, 2015, typically close to the two most popular groceries. Altogether, 91 women and 61 men helped our work with their opinion. We chose our answerers randomly, with total anonymity. We used Microsoft Excel to analyze the results and PSPP statistic system to examine the assumptions, mostly the Pearson's chi-squared test.

\section{EVALUATION OF THE RESULTS}

Hearing the name of the National Food Chain Safety Agency most of the answerers associated to control, safety and quality. The respondents evaluated on a scale how much the NÉBIH helps them to orientate with the food. The results showed that this agency helped more than $65 \%$ in a way, and only $14,14 \%$ said ,no". We compared our results with the previously mentioned Dörnyei's results made in 2009 [8]. We used three of his questions in a table form compiling our questionnaire. The table form made not only the respondents' work easier but it was also useful in the evaluation.

We got similar results - the order was almost identical - in connection with how customers/consumers get information about food. More than $60 \%$ of the respondents get information on food from their families and friends. Traditions and customs are of great importance even today but more and more people have a look at the package of the product before buying it. Scientific forums and salesrooms are in the last place.

There was not a significant difference with Dörnyei's conclusions [8] in connection with the product information either. $45 \%$ of the answerers said that they more or less know which product is worth buying on the basis of nutrition information, and that these pieces of information help their decisions. The respondents would clearly prefer that there should be more nutrition information and this kind of information is absolutely useful. However, they could not wholly agree that they can interpret the information read or heard on nutrition.

We made the following conclusions from the aspect of the marking content. Most of our answerers do not necessarily agree with the statement that they would never change their mind on the basis of the information written on the product and $41 \%$ of them do not always read the content written in ,small letters" on the product. More than $40 \%$ of the respondents think that numbers and values do not help to choose the most appropriate item. However, in case of figures and symbols there were different opinions. Most of the answerers say that it is not enough to read the product label only once to remember what was written on it and they also think that most of the time it is hardly legible. Dörnyei's results [8] are different. In approximately similar rate, the product category and the time available are important factors for our answerers to consider whether they should bother with the label or not. 
In the above-mentioned research made by Berke and Varga [11] seven features proved to be the most popular in case of a good commercial. From the aspect of giving information, it seemed to be crucial to examine which are the commercials the consumers/costumers pay attention to. The respondents in Földeák preferred the meaningful, brief, informative, honest, trustworthy and real advertisements. So it may be concluded that only these types of ads are the ones that can reach them.

Our assumptions were the following:

Among consumers with different financial backgrounds asked by us only those with higher income regard safety and quality more important than price.

This hypothesis turned to be correct. More customers with higher income chose this option, altogether $24,24 \%$. By means of chi-squared test we examined whether there is a connection between the financial background and the given influencing factors. The significance level is 0,03 . Since this value is under 0,05 , the counter-hypothesis, which shows a clear connection, can be accepted.

Consumption of healthy food is important only for consumers who consider their state of health average or under average.

It was not proved. We examined the results with crosstabs and we saw that consumption of healthy food is essential for $35 \%$ of answerers with average or lower state of health, while for more than $40 \%$ of above the average. We carried out the Pearson's chi-squared test. The significance level is 0,14 , so the null hypothesis regarding the lack of connection can be accepted.

Only those with higher education of the respondents can interpret the heard and read information on nutrition.

The hypothesis was accepted because $43,33 \%$ of the answerers with college or university or higher degree agreed with the statement that they can generally interpret the information heard or read about nutrition. The Pearson's chi-squared test resulted in the significance level of 0,01 , so it can be concluded that there is a connection between the two variables.

The National Food Chain Safety Agency helps consumers of Földeák to get the necessary information on food.

The hypothesis proved to be correct. About $40 \%$ of the answerers think that the National Food Chain Agency give a lot of help. Only around $30 \%$ said that the agency does not or just hardly helps with the information.

Respondents above 65 pay a special attention to buy Hungarian, domestic or home-processed products.

This assumption was not accepted. We can conclude that only 9,52\% of respondents above 65 prefer buying Hungarian, domestic or home-processed food. However, the age groups 18-24 and 25-34 are more consciously choose these kinds of products. I examined the connection between the two variables with the Pearson's chi-squared test which resulted in accepting the null hypothesis saying that there is no connection of this kind between the age and such products.

\section{CONCLUSIONS}

The evaluation of the primary research showed that the NÉBIH helps consumers/costumers a lot to get information, however, 31 answerers could not answer what the first thing that comes into their mind of it. Communication with consumers is very important the first place of which is the advertisement. Our respondents clearly stated their preferences on commercials. A meaningful, informative, brief and trustworthy commercial would be the proper tool to promote safe, quality food. Observation of markers and product information is getting more popular but still only people with higher education can understand them since these pieces of information include chemical components and numbers and are not always legible. The respondents, depending on their financial background, tend to place the product price before quality, safety and health. Among our answerers it is mainly the age group 18-34 that considers buying Hungarian, domestic or home-processed products important. We continued the research with a much bigger sample already. 


\section{ACKNOWLEDGEMENT}

This research has been supported by the Ministry of Human Capacities, Human Capacities Grant Management Office and the National Talent Program (Proj. No NTP-HHTDK-017-0004).

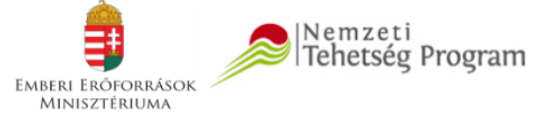

\section{REFERENCES}

[1] Szakály Z., Táplálkozásmarketing, Mezőgazda Kiadó, Budapest, 2011.

[2] Szakály Z., Élelmiszer-marketing, Akadémiai Kiadó, Budapest, 2017.

[3] Soós M., A helyi (lokális) élelmiszer-marketing összefüggésrendszere, In: Szakály Z (szerk.) Élelmiszermarketing, Akadémiai Kiadó, Budapest, 2017.

[4] Gál T., Soós M., Szakály Z., Applying new innovative market research methods in the innovation process of new products, International Journal of Engineering and Management Sciences/Müszaki és Menedzsment Tudományi Közlemények, 2.:(3.) pp. 56-69. 2017.

[5] Laczay P., Élelmiszer-higiénia Élelmiszerlánc-biztonság, Mezőgazda Kiadó, Budapest, 2013.

[6] Kiss M., Szakály Z., Soós M., Kontor E., Az egészségtudatosság megjelenése a magyar lakosság táplálkozási szokásaiban korcsoportonként, In: Bíró L., Gelencsér É., Lugasi A., Rurik I.(szerk.) A 60 éves Magyar Táplálkozástudományi Társaság XLI. vándorgyülése: Program és az előadások kivonatai, Esztergom, Magyarország, 2016.10.06-2016.10.08. Budapest: Magyar Táplálkozástudományi Társaság, p. 38., 2016.

[7] Lehota J., Az élelmiszerfogyasztással kapcsolatos észlelt kockázatok és kockázatkezelési alternatívák, Élelmiszer, táplálkozás és marketing, 3.(1), 2006.

[8] Dörnyei K., Fogyasztói magatartásvizsgálatok az élelmiszereken található információtartalomról- a jelölések, cimkék és label használatának elemzése, Marketing és menedzsment, 44. (4), 2010.

[9] Szakály Z, Polereczki Zs, Jasák H, Fehér A, Soós M., A fogyasztók egészség magatartása: 500 fös Országos reprezentatív kérdőíves lakossági felmérés, 2014.

[10] Szakály Z., Horvát A., Soós M., Pető K., Szente V., A minőségre és származásra utaló jelölések szerepe a fogyasztói döntéshozatalban, Élelmiszer, Táplálkozás és Marketing 10:(1) pp. 3-10., 2014.

[11] Berke Sz., Varga Á., Reklámstratégiák fogyasztói megítélése egyes funkcionális élelmiszereknél, kiemelten a tej-és tejtermékek példáján, Élelmiszer, táplálkozás és marketing, 5.(2-3), 2008.

[12] Malhotra N. K., Marketingkutatás, Akadémiai Kiadó, Budapest, 2008. 